\title{
Simultaneous effect of irradiance and temperature on biochemical composition of the microalga Pavlova lutheri
}

\author{
Ana P. Carvalho • Cristina M. Monteiro • \\ F. Xavier Malcata
}

\author{
A. P. Carvalho $\cdot$ C. M. Monteiro $\cdot$ F. X. Malcata $(\square)$ \\ Escola Superior de Biotecnologia, Universidade Católica \\ Portuguesa, Rua Dr. António Bernardino de Almeida, \\ P-4200-072 Porto, Portugal \\ e-mail: fxmalcata@esb.ucp.pt
}

Keywords Biochemical parameters · Irradiance . Microalga $\cdot$ Physiological status $\cdot$ Temperature

\begin{abstract}
The biochemical composition of microalgae can be modulated through the environmental conditions prevailing during growth. The simultaneous effects of irradiance and temperature on the biochemical composition of Pavlova lutheri were evaluated using an experimental star factorial design. Five levels were tested for each parameter (temperature, $10,14,18,22$ and $26^{\circ} \mathrm{C}$; irradiance, $60,105,150,195$ and $240 \mu \mathrm{mol}$ photons $\mathrm{m}^{-2} \mathrm{~s}^{-1}$ ), whereas the carbohydrate, protein, lipid, pigments and elementary compound contents were measured as response variables. Additionally, in order to rapidly measure parameters to define the status of the culture, the validation of the relationships between biochemical parameters and physiological status were estimated through regression analysis. It was observed that irradiance and temperature play a major role in the determination of the biochemical composition of microalgae. Their effects are synergistic, and it can be observed that a trend in behaviour at a certain temperature can be reversed at a different temperature; therefore, when selecting the environmental conditions to a culture they must be studied in a combined fashion. Although there are consistent relationships between pigment contents and elementary compounds in cells, its linearity is influenced by the irradiance of the culture and its age; therefore, they can only be applied in specific circumstances. On the other side, population biomass was well estimated in terms of carotenoid content, irrespective of the environmental conditions provided and the growth phase.
\end{abstract}

\section{Introduction}

Microalgal cultures represent an essential and costly step in aquaculture. They are essential because they are employed to feed bivalves at all stages of growth, as well as zooplankton (rotifers, copepods and brine shrimps), which will in turn be used to feed crustaceans and fish in larval stages (Volkman et al. 1989); they are a costly step, which may represent $50 \%$ of the entire hatchery management costs, because cultivation techniques require considerable human and economic investment (Ponis et al. 2006). Therefore, studies leading to a reduction in cultivation costs are essential, which may be dedicated to the optimization of the culture system (Ponis et al. 2006) or the optimization of the physical-chemical conditions to which the culture is subjected, aiming at enriching the biochemical composition of the microalga.

Regarding the latter, sufficient conditions for microalgal growth encompass both chemical substrates (e.g. macro- and micro-nutrients) and physical "substrates" (e.g. temperature and irradiance, which are in essence forms of thermal and radiant energy). In terms of physical "substrates", light and temperature have been widely accepted as the driving factors acting on overall biochemical composition in algal cultures (Dermoun et al. 1992; Trabelsi et al. 2008). Light is essential for autotrophic organisms to obtain chemical energy, stored in reduced carbon compounds (Dubinsky et al. 1995), whereas the effects of temperature on cell cultures concern mainly two factors: one relates to the temperature dependence of the structure of cell components (especially proteins and lipids), and the other pertains to the 
temperature dependence of reaction rates, which in turn depend on the activation energies of those reactions. As a consequence of these primary effects, there are also secondary effects on metabolic regulatory mechanisms, specificity of enzyme reactions, cell permeability and cell composition (Richmond 1986).

Microalgae respond to physicochemical variations in the surrounding environment, but the nature and extent of such environmental interactions is not yet fully understood. Contributions thereto have been made available, either encompassing chemical substrates (Ayala and Bravo 1984; Spektorova et al. 1986), physical "substrates" (Rochet et al. 1985; Joo et al. 1998; Spolaore et al. 2006; ValenzuelaEspinoza et al. 2007; Baek et al. 2008) or both (Sukenik et al. 1993; Vonshak et al. 2000; Otero and Vincenzini 2003; Araújo and Garcia 2005); however, such results are often ambiguous, because of the different experimental conditions employed, which may exert simultaneous, yet antagonist effects (Harding et al. 1985). Besides, extrapolations from studies using a one-variable-at-a-time (OVAT) approach do not allow the study of the possible interactions between the different factors; there is in fact evidence that some species may shift their acclimation strategies from strictly linear and independent behaviours in response to combinations of both factors (Thompson 1999). Therefore, it is of great interest to experimentally establish the single and interaction effects of irradiance and temperature on microalgal cultures, with the final goal of maximizing its biochemical profile and concomitantly reducing costs. The microalga selected was the marine phytoflagellate Pavlova lutheri (Droop) Green (Pavlovophyceae), because of its extensive use in aquaculture industry (Ponis et al. 2006).

The aim of this work was to evaluate the simultaneous influence of irradiance and temperature on the biochemical composition of $P$. lutheri, by using several combinations of irradiance and temperature, laid out as a star factorial scheme. To that end, the gross composition of the microalga cultured in the different conditions was analysed.

Additionally, the establishment of relationships between biochemical parameters and the physiological state of the culture was also sought, with the final goal of identifying parameters that would be easily monitored and might rapidly give indications about the current status of the culture. In fact, although there are reports on the relationships between the amount of chlorophyll $a$ and the nitrogen quota, or the content of carotenoid and the carbon quota (Clark 2001), such relationships were tested for cultures submitted to variations of chemical nutrients only, rather than to variations of physical conditions. In this work we attempted to overcome this limitation, by validation or limitation of those relationships, in order to define their limits of application. Specifically, this study concerned the validity of using pigment contents to estimate biomass and the relationship between such pigment contents and the internal amounts of elementary compounds, in microalgal cultures submitted to variations in their environmental conditions.

\section{Materials and methods}

Pavlova lutheri (SMBA 60) was obtained from the reference collection held by Instituto Português de Investigação MARítima (IPIMAR), Portugal.

Cultures were grown in batch mode, in $250-\mathrm{mL}$ Erlenmeyer flasks, with ASW culture medium modified as described elsewhere (Carvalho and Malcata 2003). Culture flasks were incubated in a Gallenkamp orbital incubator (Sanyo, UK), stirred at $100 \mathrm{rpm}$ and submitted to the desired temperature and light regimes (Fig. 1). The choice of levels of the factors was based on information from literature and preliminary experiments. Irradiance (Sylvania GRO-LUX ${ }^{\circledR}$ F30W lamps) was measured as Photosynthetic Active Radiation (PAR) with an LI-190SA Quantum Sensor, coupled to an LI-1000 Data Logger. Before each experiment, cultures remained at the determined experimental conditions for an adaptation period of approximately four generations. Forced aeration was not provided. Initial cell concentrations were similar in all experiments (ca. $4 \times 10^{5}$ cell $\mathrm{mL}^{-1}$ ). Sampling was performed by random selection and recovery of, at least, three flasks in each harvesting day along the growth cycle. The various experiments were carried out in randomized order and in duplicate. Cultures were allowed to grow until either late exponential phase or early stationary phase. The experiment intended to be held at $14^{\circ} \mathrm{C}$ and $105 \mu \mathrm{mol}$ photons $\mathrm{m}^{-2} \mathrm{~s}^{-1}$ was not performed, because it was found (from extrapolation of the other experiments) that such region was not interesting towards high values of biochemical parameters (as desired).

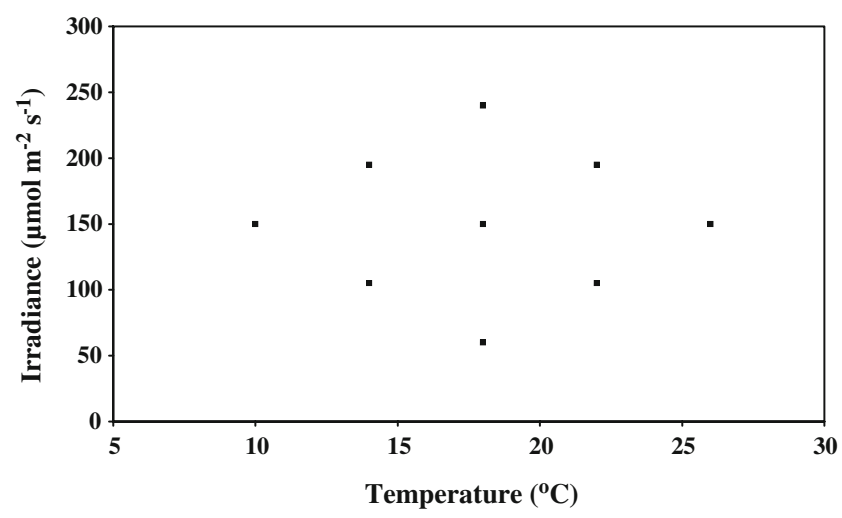

Fig. 1 Experimental design, in terms of irradiance ( $\mu \mathrm{mol}$ photons $\mathrm{m}^{-2}$ $\left.\mathrm{s}^{-1}\right)$ and temperature $\left({ }^{\circ} \mathrm{C}\right)$ 
Analytical assaying

Determinations of cell number were performed with a Neubauer Improved bright-line haemocytometer. Ash free dry weight was determined by filtering $10 \mathrm{~mL}$ of culture through pre-conditioned Whatman $\mathrm{GF} / \mathrm{C}$ glass fibre filters, drying at $100^{\circ} \mathrm{C}$ to constant weight and heating at $550^{\circ} \mathrm{C}$ to eliminate the organic material.

\section{Biochemical composition}

The total protein content was assayed by the Lowry method (Lowry et al. 1951), after previous hydrolysis in $2 \mathrm{M} \mathrm{NaOH}$ for $15 \mathrm{~min}$ in an ultrasonicator, and a further treatment at $100^{\circ} \mathrm{C}$ for $5 \mathrm{~min}$ to dissolve proteins. Bovine serum albumin was used as standard. Total carbohydrates were quantified as glucose equivalent, according to the phenol/sulphuric acid method (Dubois et al. 1956). Total lipids were determined gravimetrically by the Bligh-Dyer method (Bligh and Dyer 1959). The pigment contents were estimated spectrophotometrically after overnight extraction with 100\% acetone saturated with magnesium hydroxide carbonate at $4^{\circ} \mathrm{C}$ in the dark (Jeffrey and Humphrey 1975). Intracellular contents of carbon, nitrogen, phosphorus and sulphur were determined with a Fisons EA1108 Elemental Analyser, via combustion of the sample followed by isothermal chromatographic analysis of the resulting gases using a thermal conductivity detector; helium was used as eluent gas, and the stationary phase was composed of Porapak.

\section{Statistical analyses}

Principal Component Analysis (PCA) of the data was performed with the XLSTAT software (Microsoft Excel, USA). Unpaired comparison of the overall dataset was performed with the software StatView ${ }^{\mathrm{TM}}$ (Abacus Concepts, USA). Regression analysis was used to test for relationships among data.

\section{Results}

Due to the (intrinsic) variability of results along the growth curves, the effects of temperature and irradiance on the biochemical profiles of the microalga should be studied independently for each growth phase. Since exponential growth phase encompasses growth conditions for which there is no nutrient limitation, it is the most adequate phase to pinpoint those physical effects on growth.

Figure 2 describes the cell quotas of biochemical and elemental compounds in the mid-exponential growth phase, at the various combinations of temperature and irradiance studied. By inspection of such figure it can be observed that internal carbohydrate content in the exponential growth phase increases with temperature for an irradiance of $150 \mu \mathrm{mol}$ photons $\mathrm{m}^{-2} \mathrm{~s}^{-1}$ whereas it decreases for an irradiance of $195 \mu \mathrm{mol}$ photons $\mathrm{m}^{-2} \mathrm{~s}^{-1}$. Light also causes an opposite effect at the two temperatures studied: carbohydrate content increases with irradiance up to $150 \mu \mathrm{mol}$ photons $\mathrm{m}^{-2} \mathrm{~s}^{-1}$ for a temperature of $18^{\circ} \mathrm{C}$, and slightly decrease afterwards; at $22^{\circ} \mathrm{C}$, carbohydrates decrease in concentration with irradiance. The highest value of carbohydrate content obtained from these combinations of environmental parameters was $9.26 \mathrm{pg} \mathrm{cell}^{-1}$, in the experiment carried out at $26^{\circ} \mathrm{C}$ and $150 \mu \mathrm{mol}$ photons $\mathrm{m}^{-2} \mathrm{~s}^{-1}$; such result was statistically different from the remaining.

Protein contents also showed varying trends: they decreased with increasing temperature (at the two irradiances tested), increased with irradiance for a constant temperature of $18^{\circ} \mathrm{C}$, and decreased with irradiance for a constant temperature of $22^{\circ} \mathrm{C}$. However, the observed variations among experiments performed at a constant temperature of $22^{\circ} \mathrm{C}$ are not statistically different among each other. Cells maximized their protein content at environmental conditions of $14^{\circ} \mathrm{C}$ and $195 \mu \mathrm{mol}$ photons $\mathrm{m}^{-2} \mathrm{~s}^{-1}$ reaching $33.7 \mathrm{pg}$ cell $^{-1}$, a value significantly different from the remaining.

Lipid content in general decreased with increasing temperature, although not significantly; the response to irradiance was more inconsistent, increasing up to $150 \mu \mathrm{mol}$ photons $\mathrm{m}^{-2} \mathrm{~s}^{-1}$ and decreasing afterwards. The highest lipid content $\left(8.4 \mathrm{pg} \mathrm{cell}^{-1}\right)$ was obtained at $10^{\circ} \mathrm{C}$ and $150 \mu \mathrm{mol}$ photons $\mathrm{m}^{-2} \mathrm{~s}^{-1}$, not statistically different from the value obtained at $18^{\circ} \mathrm{C}$ under the same irradiance.

Internal quotas of carbon, nitrogen and sulphur increased with temperature for experiments run at constant irradiances of 150 and $195 \mu \mathrm{mol}$ photons $\mathrm{m}^{-2} \mathrm{~s}^{-1}$. Regarding the influence of irradiance, it was realized that the three quotas increased with light at $18^{\circ} \mathrm{C}$ up to $150 \mu \mathrm{mol}$ photons $\mathrm{m}^{-2} \mathrm{~s}^{-1}$, but decreased at $22^{\circ} \mathrm{C}$. Largest amounts of carbon (11.8 pg cell $\left.{ }^{-1}\right)$, nitrogen $\left(3.5 \mathrm{pg} \mathrm{cell}^{-1}\right)$ and sulphur (18.6 pg cell ${ }^{-1}$ ) were achieved during the experiment performed at $18^{\circ} \mathrm{C}$ and $150 \mu \mathrm{mol}$ photons $\mathrm{m}^{-2} \mathrm{~s}^{-1}$, whereas phosphorus $\left(0.39 \mathrm{pg} \mathrm{cell}^{-1}\right)$ was obtained at $22^{\circ} \mathrm{C}$ and $105 \mu \mathrm{mol}$ photons $\mathrm{m}^{-2} \mathrm{~s}^{-1}$.

Regarding pigments, a decrease in the contents of chlorophyll $a$ with irradiance has been observed, with the highest pigment content $\left(0.47 \mathrm{pg} \mathrm{cell}{ }^{-1}\right)$ obtained at $18^{\circ} \mathrm{C}$ and $60 \mu \mathrm{mol}$ photons $\mathrm{m}^{-2} \mathrm{~s}^{-1}$, although not statistically different from the value obtained at $22^{\circ} \mathrm{C}$ and $105 \mu$ mol photons $\mathrm{m}^{-2} \mathrm{~s}^{-1}$. The total carotenoid content per cell increased with irradiance, reaching its maximum at $18^{\circ} \mathrm{C}$ and $240 \mu \mathrm{mol}$ photons $\mathrm{m}^{-2} \mathrm{~s}^{-1}$, again not statistically different from the value obtained at $18^{\circ} \mathrm{C}$ and $150 \mu \mathrm{mol}$ photons $\mathrm{m}^{-2} \mathrm{~s}^{-1}$. Both chlorophyll $a$ and carotenoid contents consistently increased with temperature, irrespective of the irradiance. 


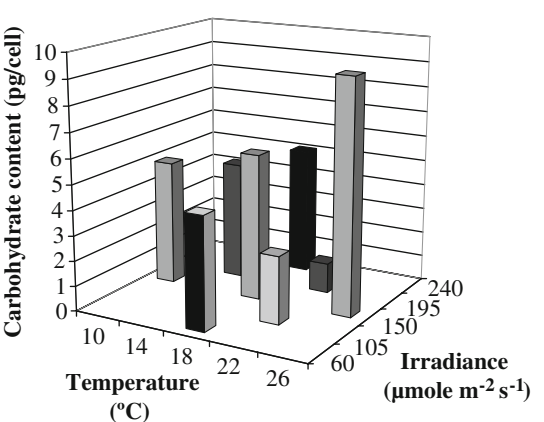

$\left({ }^{\circ} \mathrm{C}\right)$

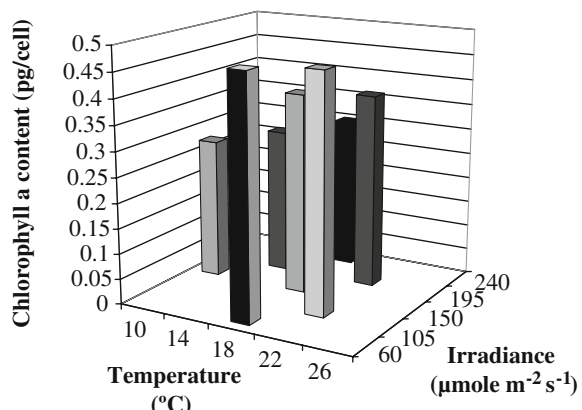

$\left({ }^{\circ} \mathrm{C}\right)$

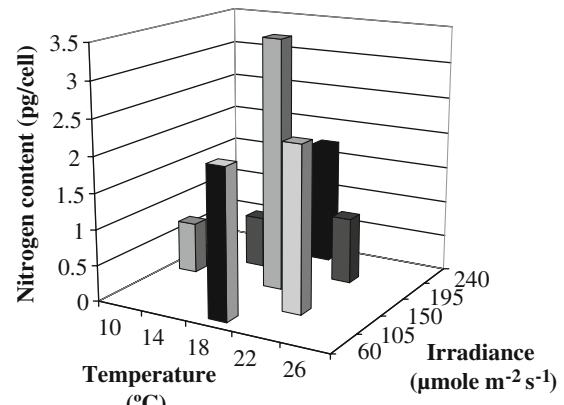

$\left({ }^{\circ} \mathrm{C}\right)$

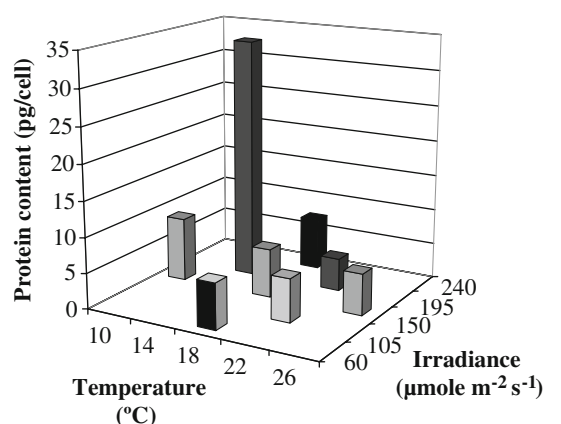

$\left({ }^{\circ} \mathrm{C}\right)$

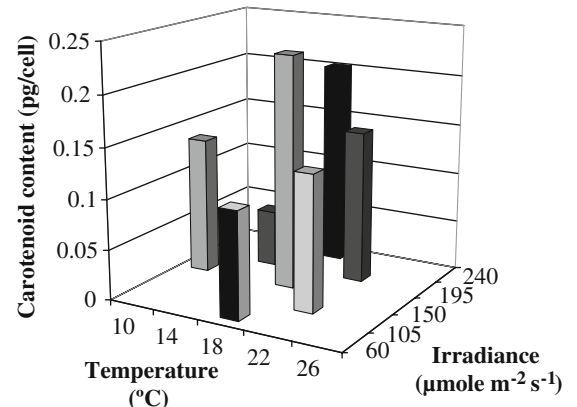

$\left({ }^{\circ} \mathrm{C}\right)$

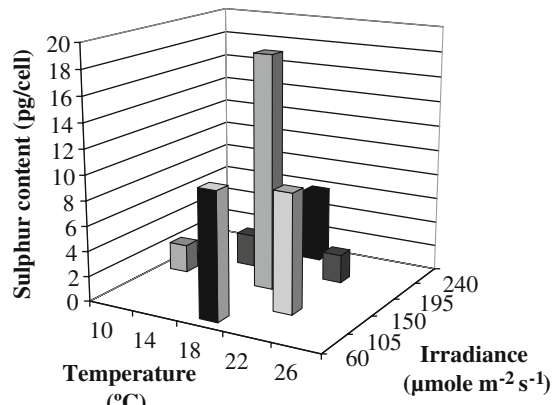

$\left({ }^{\circ} \mathrm{C}\right)$
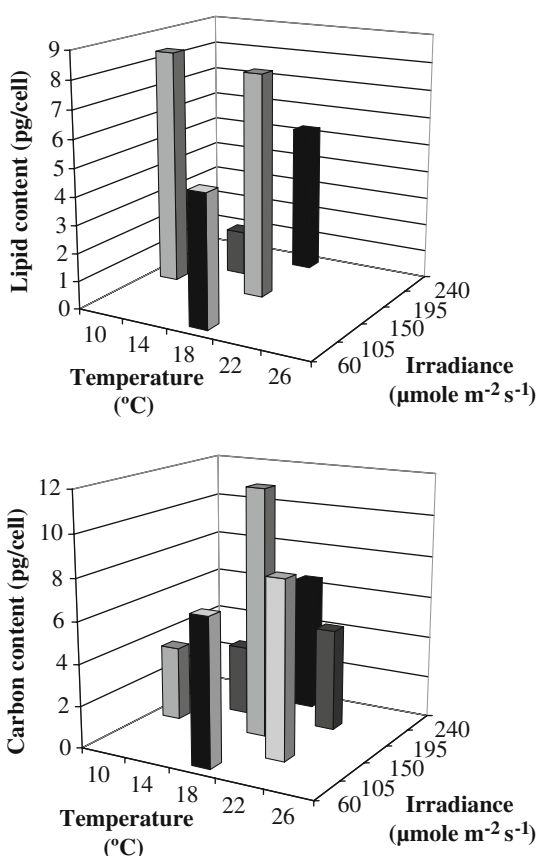

$\left.{ }^{\circ} \mathrm{C}\right)$

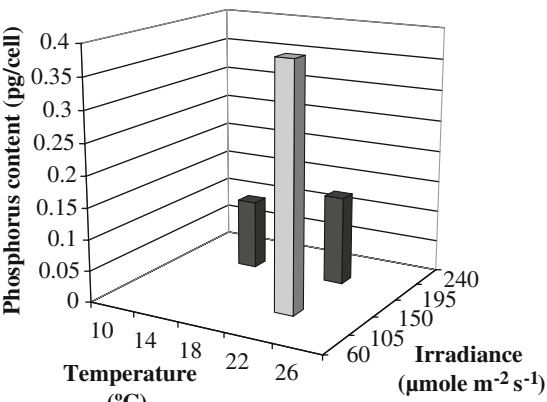

$\left({ }^{\circ} \mathrm{C}\right)$

Fig. 2 Cellular quotas of biochemical and elementary compounds in the mid-exponential growth phase, at various combinations of temperature and irradiance

In order to screen for potential relationships between the various biochemical parameters studied, Principal Component Analysis (PCA) was carried out with the biochemical parameters obtained in the whole set of experimental conditions of light and temperature tested, and by using all the sampling points generated during the exponential, late exponential and early stationary growth phases of each experimental combination tested. PCA is a statistical technique for mapping multidimensional data into lower dimensions, with minimal loss of information. This method explains the variance of the data matrix in terms of new latent variables (called Principal Components), which are linear combinations of the initial ones-if there is a correlation between the data, a small number of Principal Components will summarize the majority of the variation within the matrix. When applying PCA to the data in terms of internal amounts per cell (i.e., quotas), two new variables ( $\mathrm{PC} 1$ and $\mathrm{PC} 2)$ together described $58 \%$ of the total variance of the initial matrix, as described in Fig. 3. The correlation coefficients obtained with those first two components are presented in Table 1: PC1 is controlled by the quotas of carbon, nitrogen and sulphur, as well as by carbohydrate and chlorophyll $c$ contents; PC2 indicated correlations between the protein and chlorophyll $a$ contents, as well as the environmental parameters (temperature and irradiance). Protein content correlated positively with irradiance and negatively with temperature, while chlorophyll $a$ correlated inversely with irradiance and positively with temperature, which is in agreement with the results previously described.

From the results of PCA, it is apparent that neither chlorophyll $a$ nor protein content were suitable indicators of population biomass, since they are dependent on the prevailing environmental conditions. In fact, despite the realization that relationships between chlorophyll $a$ and cell number follow a linear trend (Fig. 4), such trend depends on the actual light regime used: from the data generated, 


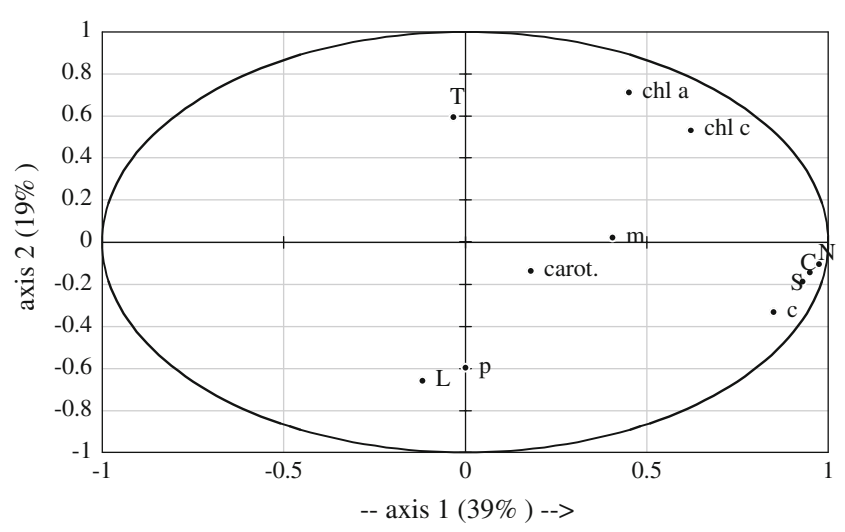

Fig. 3 PCA plot in terms of internal amounts of $s$ carbohydrate, $p$ protein (picograms per cell), chl $a$ chlorophyll $a$ (picograms per cell), chl $c$ chlorophyll $c$ (picograms per cell), carot carotenoid (picograms per cell), $C$ carbon (picograms per cell), $N$ nitrogen (picograms per cell) and $S$ sulphur (picograms per cell), and $m$ specific rate (per day), $T$ temperature $\left({ }^{\circ} \mathrm{C}\right)$ and $L$ irradiance ( $\mu$ mol photons $\mathrm{m}^{-2} \mathrm{~s}^{-1}$ )

two linear behaviours may be pinpointed, one encompassing the data points pertaining to the experiments run at lower light intensities (60 and $105 \mu \mathrm{mol}$ photons $\mathrm{m}^{-2} \mathrm{~s}^{-1}$; $\left.R^{2}=0.959\right)$, and the other including the points obtained at the higher ones $\left(R^{2}=0.863\right)$. Unlike chlorophyll $a$, the mass content of carotenoids increases linearly with cell number, irrespectively of the light-temperature regime followed (Fig. 5; $R^{2}=0.879$ ); hence, this is a more accurate measurement when estimation of population biomass is sought.

Recalling the second objective (establishment of relationships between pigment contents and the internal amounts of elementary compounds) the linear relationships between extractable carotenoid and carbon, and extractable chlorophyll $a$ and nitrogen were also studied. In what concerns the evolution of the correlation between caroten-

Table 1 Correlations between initial variables and first two principal components, in terms of internal values

\begin{tabular}{|c|c|c|c|}
\hline Parameter & symbol & PC1 & $\mathrm{PC} 2$ \\
\hline Carbohydrate content (pg.cell ${ }^{-1}$ ) & $\mathrm{c}$ & 0.8499 & -0.3326 \\
\hline Protein content (pg.cell ${ }^{-1}$ ) & $\mathrm{p}$ & 0.0003 & -0.5962 \\
\hline Chlorophyll $a$ content (pg.cell ${ }^{-1}$ ) & chl a & 0.4499 & 0.7140 \\
\hline Chlorophyll $c$ content (pg.cell ${ }^{-1}$ ) & $\operatorname{chl~c}$ & 0.6223 & 0.5327 \\
\hline Carotenoid content (pg.cell ${ }^{-1}$ ) & carot & 0.1800 & -0.1373 \\
\hline Specific rate $\left(\mathrm{d}^{-1}\right)$ & $\mathrm{m}$ & 0.4056 & 0.0221 \\
\hline Carbon content (pg.cell ${ }^{-1}$ ) & $\mathrm{C}$ & 0.9491 & -0.1425 \\
\hline Nitrogen content (pg.cell ${ }^{-1}$ ) & $\mathrm{N}$ & 0.9753 & -0.1047 \\
\hline Sulphur content (pg.cell ${ }^{-1}$ ) & $\mathrm{S}$ & 0.9294 & -0.1873 \\
\hline Temperature $\left({ }^{\circ} \mathrm{C}\right)$ & $\mathrm{T}$ & -0.0332 & 0.5966 \\
\hline Irradiance $(\%)$ & $\mathrm{L}$ & -0.1173 & -0.6569 \\
\hline
\end{tabular}

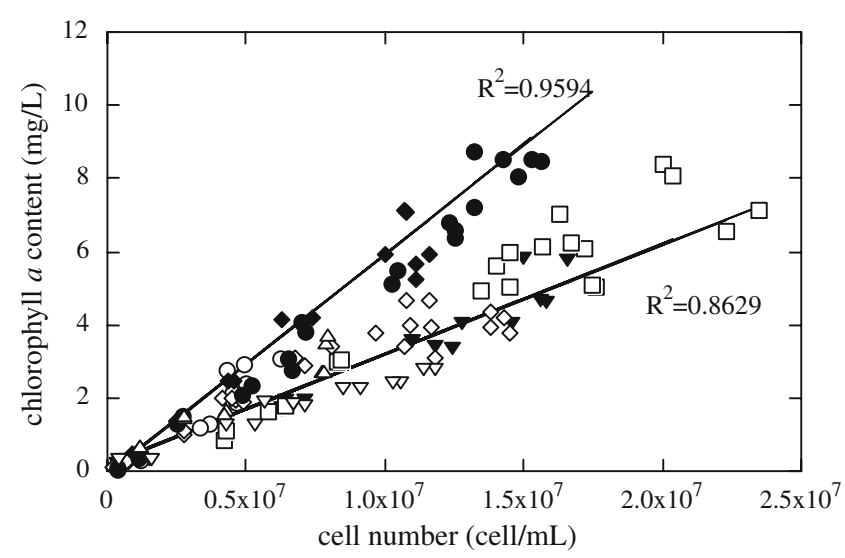

Fig. 4 Variation of the total amount of chlorophyll $a$ in the culture with the total cell number, for various combinations of temperature and irradiance: filled inverted triangle $10^{\circ} \mathrm{C}, 150 \mu \mathrm{mol}$ photons $\mathrm{m}^{-2} \mathrm{~s}^{-1}$, empty circle $26^{\circ} \mathrm{C}, 150 \mu \mathrm{mol}$ photons $\mathrm{m}^{-2} \mathrm{~s}^{-1}$, filled diamond $18^{\circ} \mathrm{C}$, $60 \mu \mathrm{mol}$ photons $\mathrm{m}^{-2} \mathrm{~s}^{-1}$, empty square $14^{\circ} \mathrm{C}, 195 \mu \mathrm{mol}$ photons $\mathrm{m}^{-2} \mathrm{~s}^{-1}$, empty diamond $22^{\circ} \mathrm{C}, 195 \mu \mathrm{mol}$ photons $\mathrm{m}^{-2} \mathrm{~s}^{-1}$, filled circle $22^{\circ} \mathrm{C}, 105 \mu \mathrm{mol}$ photons $\mathrm{m}^{-2} \mathrm{~s}^{-1}$, empty upright triangle $18^{\circ} \mathrm{C}$, $240 \mu \mathrm{mol}$ photons $\mathrm{m}^{-2} \mathrm{~s}^{-1}$, empty inverted triangle $18^{\circ} \mathrm{C}, 150 \mu \mathrm{mol}$ photons $\mathrm{m}^{-2} \mathrm{~s}^{-1}$. Experimental data obtained at the lowest light intensities ( 60 and $105 \mu \mathrm{mol}$ photons $\mathrm{m}^{-2} \mathrm{~s}^{-1}$ ) are fitted by the linear relationship $Y=-0.0763+6 \times 10^{-7} X\left(R^{2}=0.959\right)$, whereas those obtained at the higher light intensities are fitted by the linear relationship $Y=0.1959+3 \times 10^{-7} X\left(R^{2}=0.863\right)$

oid and carbon contents (Fig. 6a), the linear trend that holds initially-and which is similar for all experimentssubdivides in the late exponential and stationary phases into two lines: the upper line encompasses the experiments run at $195 \mu \mathrm{mol} \mathrm{m}{ }^{-2} \mathrm{~s}^{-1}$ irradiance, whereas the lower one is associated with the remaining experiments. At lower light

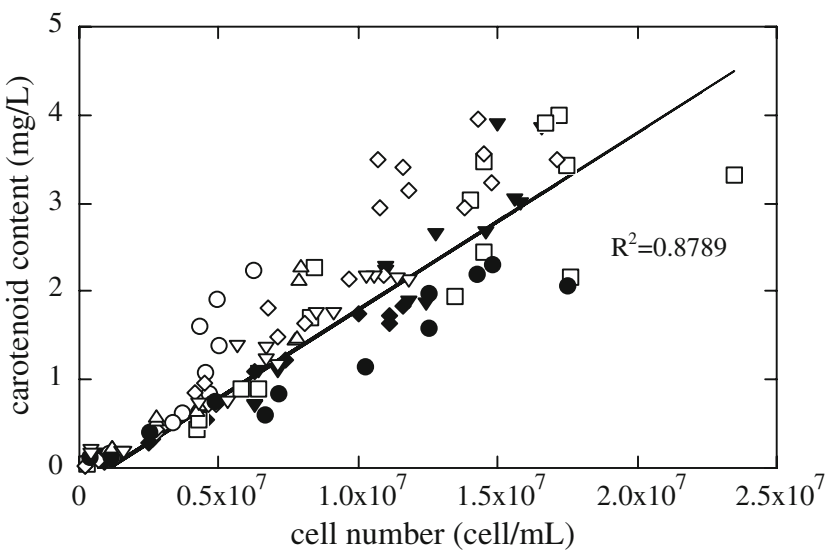

Fig. 5 Variation of the total amount of carotenoid in the culture with the total cell number, for various combinations of temperature and irradiance: filled inverted triangle $10^{\circ} \mathrm{C}, 150 \mu \mathrm{mol}$ photons $\mathrm{m}^{-2} \mathrm{~s}^{-1}$, empty circle $26^{\circ} \mathrm{C}, 150 \mu \mathrm{mol}$ photons $\mathrm{m}^{-2} \mathrm{~s}^{-1}$, filled diamond $18^{\circ} \mathrm{C}, 60 \mu \mathrm{mol}$ photons $\mathrm{m}^{-2} \mathrm{~s}^{-1}$, empty square $14^{\circ} \mathrm{C}, 195 \mu \mathrm{mol}$ photons $\mathrm{m}^{-2} \mathrm{~s}^{-1}$, empty diamond $22^{\circ} \mathrm{C}, 195 \mu \mathrm{mol}$ photons $\mathrm{m}^{-2} \mathrm{~s}^{-1}$, filled circle $22^{\circ} \mathrm{C}, 105 \mu \mathrm{mol}$ photons $\mathrm{m}^{-2} \mathrm{~s}^{-1}$, empty upright triangle $18^{\circ} \mathrm{C}, 240 \mu \mathrm{mol}$ photons $\mathrm{m}^{-2} \mathrm{~s}^{-1}$, empty inverted triangle $18^{\circ} \mathrm{C}, 150$ photons $\mu \mathrm{mol} \mathrm{m} \mathrm{m}^{-2} \mathrm{~s}^{-1}$. Experimental data are fitted by the linear relationship $Y=-0.2057+2 \times$ $10^{-7} X\left(R^{2}=0.879\right)$ 

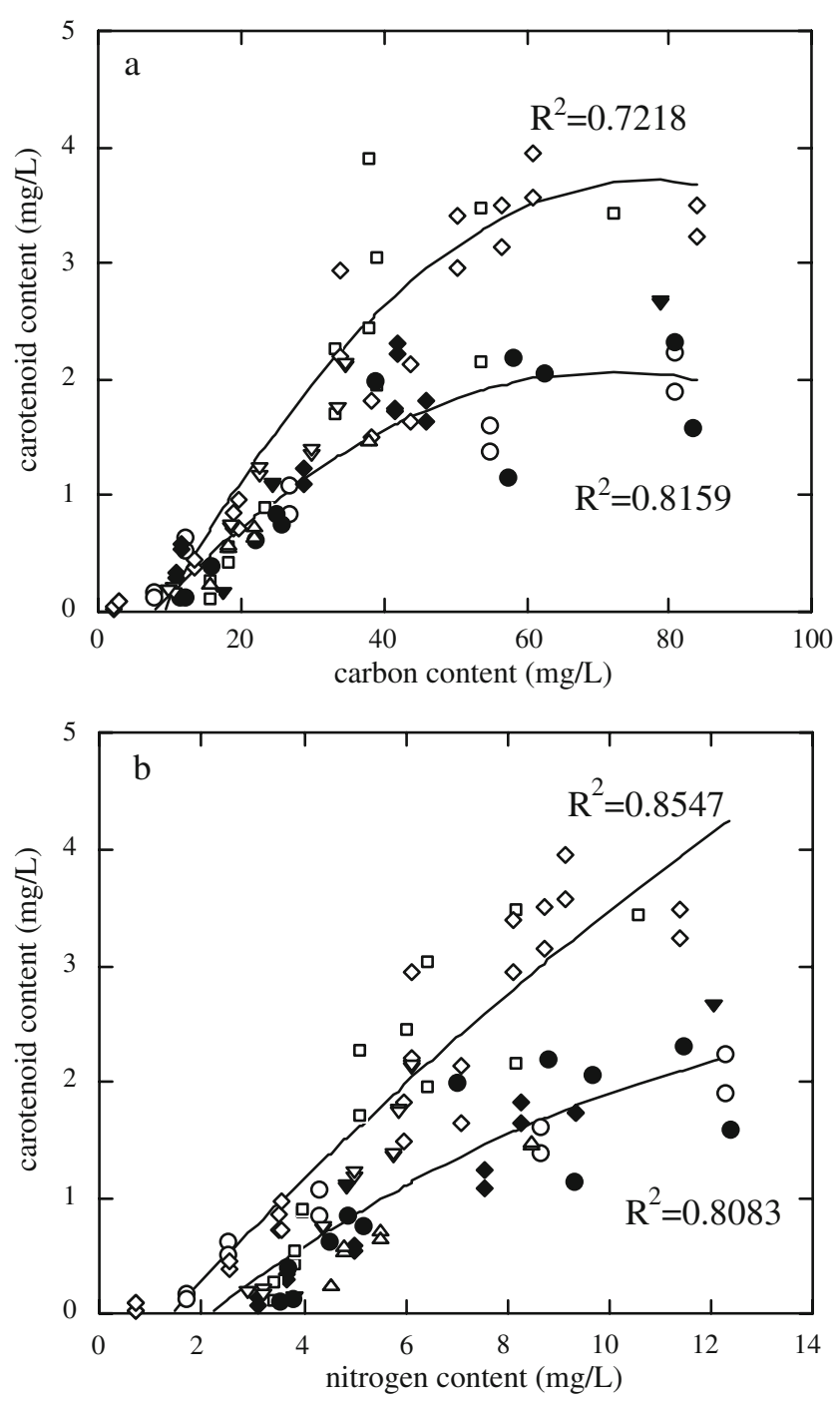

Fig. 6 Relationship between the carotenoid content of the culture and the internal amount of $\mathbf{a}$ carbon or $\mathbf{b}$ nitrogen, for various combinations of temperature and irradiance: filled inverted triangle $10^{\circ} \mathrm{C}, 150 \mu \mathrm{mol}$ photons $\mathrm{m}^{-2} \mathrm{~s}^{-1}$, empty circle $26^{\circ} \mathrm{C}, 150 \mu \mathrm{mol}$ photons $\mathrm{m}^{-2} \mathrm{~s}^{-1}$, filled diamond $18^{\circ} \mathrm{C}, 60 \mu \mathrm{mol}$ photons $\mathrm{m}^{-2} \mathrm{~s}^{-1}$, empty square $14^{\circ} \mathrm{C}$, $195 \mu \mathrm{mol}$ photons $\mathrm{m}^{-2} \mathrm{~s}^{-1}$, empty diamond $22^{\circ} \mathrm{C}, 195 \mu \mathrm{mol}$ photons $\mathrm{m}^{-2} \mathrm{~s}^{-1}$, filled circle $22^{\circ} \mathrm{C}, 105 \mu \mathrm{mol}$ photons $\mathrm{m}^{-2} \mathrm{~s}^{-1}$, empty upright triangle $18^{\circ} \mathrm{C}, 240 \mu \mathrm{mol}$ photons $\mathrm{m}^{-2} \mathrm{~s}^{-1}$, empty inverted triangle $18^{\circ} \mathrm{C}, 150 \mu \mathrm{mol}$ photons $\mathrm{m}^{-2} \mathrm{~s}^{-1}$. Plot a: experimental data obtained at the lowest light intensities $\left(60-150 \mu \mathrm{mol}\right.$ photons $\left.\mathrm{m}^{-2} \mathrm{~s}^{-1}\right)$ are fitted by the polynomial relationship $Y=-0.5165+0.0719 X-5 \times 10^{-4} X^{2}\left(R^{2}=\right.$ $0.816)$, whereas those obtained at the higher irradiances are fitted by the polynomial relationship $Y=-1.0192+0.1232 X-8 \times 10^{-4} X^{2}\left(R^{2}=\right.$ 0.722). Plot $\mathbf{b}$ experimental data obtained at the lowest irradiances (60-150 $\mu \mathrm{mol}$ photons $\left.\mathrm{m}^{-2} \mathrm{~s}^{-1}\right)$ are well-fitted by the relationship $Y=$ $-0.749+0.3738 X-0.0109 X^{2} \quad\left(R^{2}=0.808\right)$, whereas those obtained at the higher irradiances are well-fitted by $Y=-0.6504+0.4783 \mathrm{X}-$ $0.0066 X^{2}\left(R^{2}=0.855\right)$

intensities, a saturation point is apparently reached, after which there is no increase in carotenoid levels despite the increase in carbon amount; conversely, at higher light intensities $\left(195 \mu \mathrm{mol}\right.$ photons $\left.\mathrm{m}^{-2} \mathrm{~s}^{-1}\right)$ such saturation point is only reached at higher carbon amounts. The highest irradiance tested was in fact $240 \mu \mathrm{mol}$ photons $\mathrm{m}^{-2} \mathrm{~s}^{-1}$ (instead of $195 \mu \mathrm{mol}$ photons $\mathrm{m}^{-2} \mathrm{~s}^{-1}$ ), but the values obtained for the biochemical parameters in the former were always small (due to the lower running time of the experiment), and thus laid in the linear part of the plot. The dependence of carotenoid content on nitrogen content (Fig. 6-b) followed a similar trend.

The behaviour observed for the dependence of chlorophyll $a$ content on carbon content is also driven by saturation lines: the upper line pertains to the experiments run at $22^{\circ} \mathrm{C}$ and $105 \mu \mathrm{mol}$ photons $\mathrm{m}^{-2} \mathrm{~s}^{-1}$ irradiance, $18^{\circ} \mathrm{C}$ and $60 \mu \mathrm{mol}$ photons $\mathrm{m}^{-2} \mathrm{~s}^{-1}$, and $14^{\circ} \mathrm{C}$ and $195 \mu \mathrm{mol}$ photons $\mathrm{m}^{-2} \mathrm{~s}^{-1}$, whereas the lower encompasses the remaining experiments (Fig. 7a). The relationship between the pigment content and the nitrogen content (Fig. 7b) does not follow a consistent trend.

Finally, a putative linear trend was tested between the relative specific growth rate (defined as the observed specific growth rate normalized by the maximum specific growth rate) and the ratio N/C, which represents a balance between the metabolisms of $\mathrm{N}$ and $\mathrm{C}$, integrated over the whole cellular processes (Fig. 8); nevertheless, the fitting was poor $\left(R^{2}=0.594\right)$.

\section{Discussion}

The biochemical composition of Pavlova lutheri was evaluated with respect to variations in irradiance and temperature provided during growth. Discussion will be divided in two parts, one concerning the impact of environmental parameters on the biochemical profile of the microalga and the second relating the biochemical parameters among each other, in order to obtain linear correlations.

Impact of environmental parameters on biochemical profiles

The inconsistent variations observed in carbohydrate content with temperature or light had already been described: Thompson and Guo (1992) reported inconsistent variation of the internal amounts of carbohydrate with temperature for $P$. lutheri at the mid-exponential phase, under a constant radiation of $220 \mu \mathrm{mol}$ photons $\mathrm{m}^{-2} \mathrm{~s}^{-1}$. Regarding the effect of irradiance, Sukenik (1991) showed increases in carbohydrate content with light in the range 30-400 $\mu \mathrm{mol}$ photons $\mathrm{m}^{-2} \mathrm{~s}^{-1}$ at $25^{\circ} \mathrm{C}$, and decreases at higher intensities for I. galbana. Those reports suggest the rationale that a link exists between the effects of temperature and light, which may lead to inverse variations in a biochemical parameter with one effect, depending on the stated value of the other effect. 

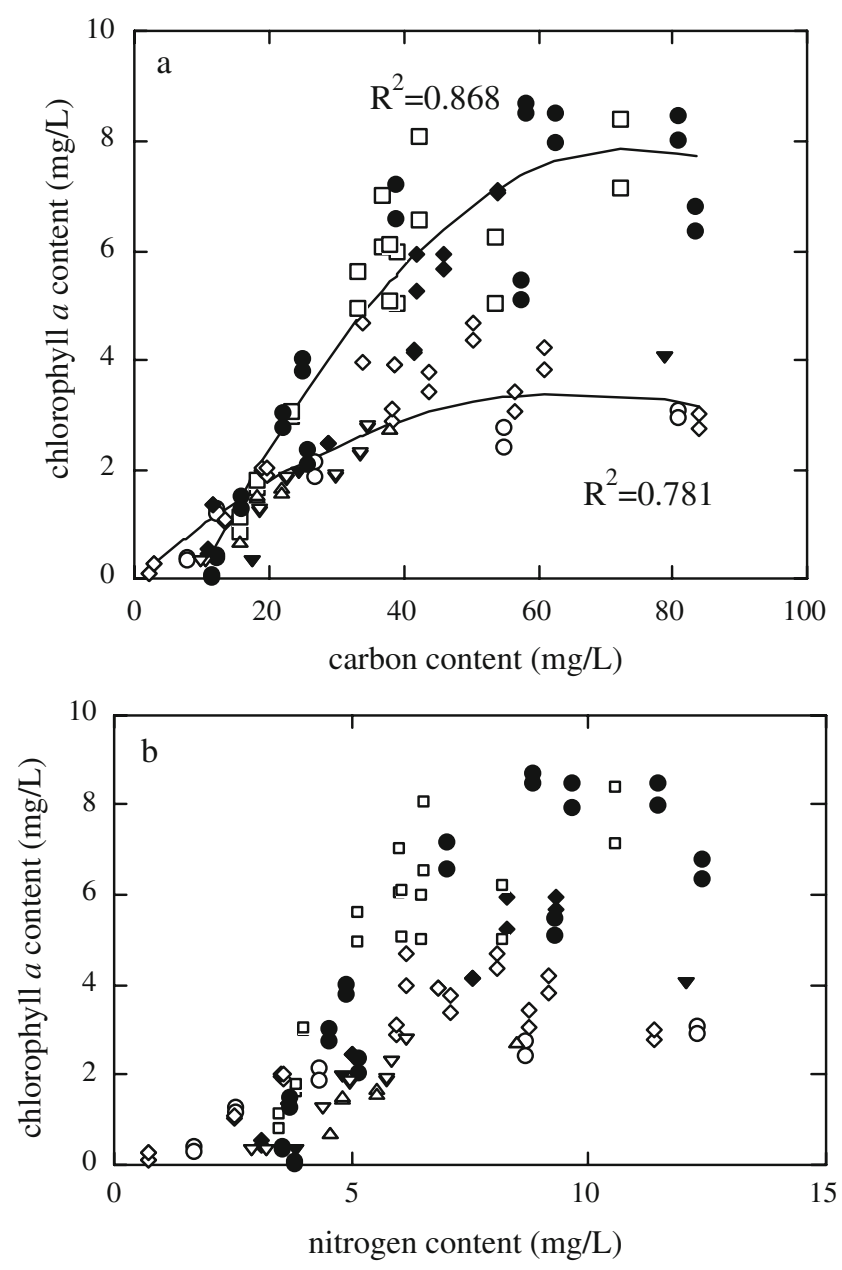

Fig. 7 Relationship between the chlorophyll $a$ content of the culture and the internal amount of $\mathbf{a}$ carbon or $\mathbf{b}$ nitrogen, for various combinations of temperature and irradiance: filled inverted triangle $10^{\circ} \mathrm{C}, 150 \mu \mathrm{mol}$ photons $\mathrm{m}^{-2} \mathrm{~s}^{-1}$, empty circle $26^{\circ} \mathrm{C}, 150 \mu \mathrm{mol}$ photons $\mathrm{m}^{-2} \mathrm{~s}^{-1}$, filled diamond $18^{\circ} \mathrm{C}, 60 \mu \mathrm{mol}$ photons $\mathrm{m}^{-2} \mathrm{~s}^{-1}$, empty square $14^{\circ} \mathrm{C}, 195 \mu \mathrm{mol}$ photons $\mathrm{m}^{-2} \mathrm{~s}^{-1}$, empty diamond $22^{\circ} \mathrm{C}$, $195 \mu \mathrm{mol}$ photons $\mathrm{m}^{-2} \mathrm{~s}^{-1}$, filled circle $22^{\circ} \mathrm{C}, 105 \mu \mathrm{mol}$ photons $\mathrm{m}^{-2} \mathrm{~s}^{-1}$, empty upright triangle $18^{\circ} \mathrm{C}, 240 \mu \mathrm{mol}$ photons $\mathrm{m}^{-2} \mathrm{~s}^{-1}$, empty inverted triangle $18^{\circ} \mathrm{C}, 150 \mu \mathrm{mol}$ photons $\mathrm{m}^{-2} \mathrm{~s}^{-1}$. Plot a: experimental data obtained at the lowest irradiances $\left(60-150 \mu \mathrm{mol}\right.$ photons $\left.\mathrm{m}^{-2} \mathrm{~s}^{-1}\right)$ are well-fitted by the polynomial relationship $Y=0.1044 X-0.0008 X^{2}\left(R^{2}=\right.$ 0.781 ), whereas those obtained at the higher irradiances are well-fitted by the relationship $Y=-2.4811+0.2806 X-0.0019 X^{2}\left(R^{2}=0.868\right)$

With respect to protein, it is known that temperature influences growth of phytoplankton primarily via control of enzyme kinetics. Hence, the increase in the proportion of carbon incorporated in proteins observed when temperature decrease mainly reflects the cell requirement for more enzymes (Jorgensen and Steeman-Nielsen 1965; Jorgensen 1968; Thompson and Guo 1992), which may obviously differ between species. Regarding irradiance, light limitation induces a deficiency in the carbon assimilated; consequently, the synthesis of chlorophyll $a$ is stimulated in order to increase the photosynthetic capacity to fix

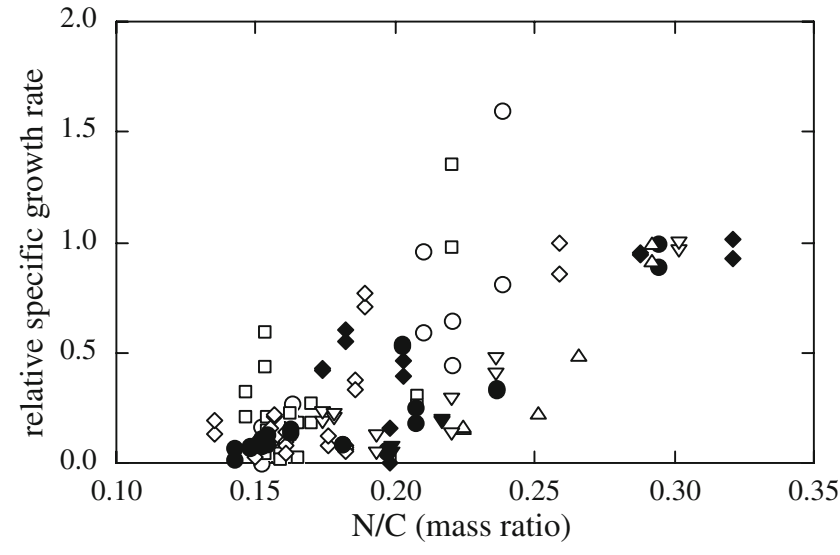

Fig. 8 Relationship between the ratio $\mathrm{C} / \mathrm{N}$ and the relative specific growth rate, for various combinations of temperature and irradiance: filled inverted triangle $10^{\circ} \mathrm{C}, 150 \mu \mathrm{mol}$ photons $\mathrm{m}^{-2} \mathrm{~s}^{-1}$, empty circle $26^{\circ} \mathrm{C}, 150 \mu \mathrm{mol}$ photons $\mathrm{m}^{-2} \mathrm{~s}^{-1}$, filled diamond $18^{\circ} \mathrm{C}, 60 \mu \mathrm{mol}$ photons $\mathrm{m}^{-2} \mathrm{~s}^{-1}$, empty square $14^{\circ} \mathrm{C}, 195 \mu \mathrm{mol}$ photons $\mathrm{m}^{-2} \mathrm{~s}^{-1}$, empty diamond $22^{\circ} \mathrm{C}, 195 \mu \mathrm{mol}$ photons $\mathrm{m}^{-2} \mathrm{~s}^{-1}$, filled circle $22^{\circ} \mathrm{C}, 105 \mu \mathrm{mol}$ photons $\mathrm{m}^{-2} \mathrm{~s}^{-1}$, empty upright triangle $18^{\circ} \mathrm{C}, 240 \mu \mathrm{mol}$ photons $\mathrm{m}^{-2} \mathrm{~s}^{-1}$, empty inverted triangle $18^{\circ} \mathrm{C}, 150 \mu \mathrm{mol}$ photons $\mathrm{m}^{-2} \mathrm{~s}^{-1}$

carbon dioxide, thus directing the assimilated carbon skeletons for pigment synthesis rather than for amino acid synthesis, as observed. Hence, it is not surprising that from the combined effects of irradiance and temperature, the highest amount of protein was obtained in the experiment performed at $14^{\circ} \mathrm{C}$ and $195 \mu \mathrm{mol}$ photons $\mathrm{m}^{-2} \mathrm{~s}^{-1}$, which is the combination of environmental conditions that includes the lowest temperature and the highest irradiance tested.

Light is the driving force of photosynthesis, as well as a major issue in cell photo-acclimatization, in the course of which phytoplankton changes its physiological properties, thereby optimizing light harvesting and utilization. At low light regimes, cells maximize use of the available energy via increasing cellular pigmentation. The decrease in contents of chlorophyll $a$ and other light harvesting pigments with increasing irradiance has been extensively described (Dubinsky et al. 1995), and is consistent with our conclusions, with the highest pigment contents obtained at 60-105 $\mu$ mol photons $\mathrm{m}^{-2} \mathrm{~s}^{-1}$ (the lowest values of irradiance tested). However, Finkel (2004) described an increase in intracellular chlorophyll $a$ content with irradiance, at very low levels of light, which shifted to an inverse relationship above a threshold value, due to a saturation effect in photon harvesting. In our study, a consistent inverse relationship between irradiance and chlorophyll $a$ was observed, because our lowest irradiance values were above the threshold value abovementioned.

Other photosynthetic pigments of this Pavlovophyceae are chlorophyll $c$ and carotenoids, which function as accessory pigments in the photosystems, as structural components of the light harvesting complexes and as photoprotective agents (Del Campo et al. 2000), thereby 
increasing with irradiance, also as observed. There are quite few studies concerning the effect of temperature on the internal production of pigments by microalgal cells. In our study, both the chlorophyll $a$ and the carotenoids increased in content with temperature, a result consistently observed at all light intensities considered. Thompson (1992) also observed the general trend of chlorophyll $a$ content to increase with temperature in eight different phytoplankton species, which suggests a common pattern of decrease in energy saturation with increasing temperature. Sukenik (1993) reported increases in both chlorophyll $a$ and carotenoid contents with temperature in cultures of Nannochloropsis sp., whereas Del Campo et al. (2000) described a stimulated production of lutein, a carotenoid from Muriellopsis sp., when temperature increased. A possible explanation for the latter lies on the assumption that the endogenously generated active oxygen is responsible for stimulation of carotenogenesis, which is a process observed at high temperature in Haematococcus spp. (Borowitzka 1988). The consistency of the results produced is, however, hardly coincidental, so there seems to be a relationship between temperature and internal production of photosynthetic pigments; further research is, nevertheless, required in order to fully clarify this issue.

One interesting conclusion from the overall data obtained is that the trend observed for the biochemical parameters versus temperature depends on the (constant) irradiance at which the experiments are conducted, and may be reversed at another irradiance; e.g., the carbohydrate amount increased with irradiance when experiments were performed at $18^{\circ} \mathrm{C}$, but decreased with irradiance at $22^{\circ} \mathrm{C}$. Similar behaviours were recorded for experiments performed at constant irradiance and varying temperatures. In an interesting study conducted outdoors with algal cultures, Vonshak (2000) described how a de-synchronization between irradiance and temperature supplied to the culture resulted in a stress condition, where photoinhibition was induced at relatively low light intensities. Consequently, extrapolations from behaviours with one set of physical conditions to another should be done with care.

Relationships between biochemical parameters and physiological status

In phytoplankton studies, the possibility of using pigment contents as indicators of carbon and nitrogen contents, nutrient status and growth rate, i.e., the physiological properties (status) of the culture, have been frequently postulated. Apart from allowing a deeper knowledge on the biochemical pathways inside the cells, those indicators also permit a substantial reduction in the number of variables necessary to characterize the algal population (Davidson et al. 1991).
Our analysis concerns two objectives: the validity of using pigment contents to estimate biomass, and the relationship between such pigment contents and the internal amounts of elementary compounds. The latter is timeconsuming to determine, so if there is a substantiated relationship between a cellular quota of an elementary compound and a pigment (easier to quantify), the quantification of pigment contents will allow the simultaneous determination of biomass and elementary compounds, with enormous savings of time and efforts.

Regarding the first objective, chlorophyll $a$ is often used to estimate phytoplankton biomass, although this pigment is strongly influenced by incident irradiance. In fact, low irradiance induces the cells to increase their chlorophyll content, as seen before; cells exposed to high irradiance will use fewer resources for chlorophyll synthesis than for synthesizing other enzymes implicated in the dark phase of photosynthesis (Fuentes et al. 2000). Furthermore, even under constant rates of illumination, nutrient depletion causes immediate discontinuation of chlorophyll $a$ synthesis, although cell division continues (until the minimum cellular content of the limiting nutrient is attained; Madariaga 1992). Therefore, it is of the utmost importance to clearly establish the physical-chemical constraints for every relationship established, because distinct environmental factors may exert simultaneous, yet dissimilar influences on the phytoplankton metabolic pathways.

From the results depicted in Figs. 4 and 5, it can be stated that conclusions encompassing population biomass based on the content of chlorophyll $a$ should be drawn carefully when irradiance is not held constant. As the mass content of carotenoids increases linearly with cell number, irrespectively of the light-temperature regime followed, this is a more accurate measurement when estimation of population biomass is sought.

Recalling the second objective, the linear relationships between extractable carotenoid and carbon, and extractable chlorophyll $a$ and nitrogen (Clark et al. 1999; Davidson et al. 1991) were also studied. The published results were obtained from samples collected after the logarithmic phase, in batch cultures with nitrogen or carbon as limiting or excess nutrients, under constant irradiance and temperature. Our study, which used various irradiances and temperature regimes during the whole growth curve, suggests that the dependence of pigment content on the internal nutrients does not seem to be influenced by the said environmental conditions, although it is influenced by the growth curve. Such behaviour seems to be related to a deficiency in light, which is noted first in the cultures submitted to lower light intensities, and is emphasized during the stationary growth phase of the cycle (which correlates to the experimental points with the highest carbon content). Hence, the conclusions previously drawn 
regarding direct relationships between carotenoid content and intracellular levels of carbon and nitrogen are also valid for experiments with variable conditions of light and temperature.

The behaviour observed for the dependence of chlorophyll $a$ content on carbon content and the relationship between the pigment content and the nitrogen content are valid for the whole growth curve rather than for only part of it, as is sometimes described in the literature.

Finally, the tentative trend tested between the relative specific growth rate and the ratio N/C, gave a poor fitting. Clark (2001) reported different behaviours for the carbon specific growth rate versus N/C for two marine diatoms in batch cultures, either $\mathrm{C}$ - or N-replete, depending on the nutrient being depleted; those studies, which were undertaken at constant irradiance $\left(200 \mu \mathrm{mol}\right.$ photons $\left.\mathrm{m}^{-2} \mathrm{~s}^{-1}\right)$ and temperature $\left(18^{\circ} \mathrm{C}\right)$, suggested that such a relationship may be class-specific. Our results seem to indicate that such relationships are also environmental-dependent.

\section{Conclusion}

The effects of irradiance and temperature in the biochemical composition of $P$. lutheri cells are synergistic, and it can be observed that a trend in behaviour produced at a certain temperature is reversed at a different temperature; therefore, when optimizing the environmental conditions in a culture they must be studied simultaneously.

The relationship between carotenoid content and cell numbers is independent of the environmental conditions prevailing in the culture and can thus be used to monitor cell growth. On the other side, although there are consistent relationships between pigment contents and elementary compounds in cells, its linearity is influenced by the irradiance of the culture and its age; therefore, they can only be applied in specific circumstances.

Acknowledgements A. P. Carvalho received a fellowship from the Portuguese Foundation for Science and Technology (Fundação para a Ciência e Tecnologia, FCT, Portugal; SFRH/BPD/26424/2006), funded by the POCI 2010 program, with the support of FSE (Fundo Social Europeu). C. M. Monteiro received a grant (BD/2838/93-IF) from PRAXIS XXI (FCT, Portugal).

\section{References}

Araújo SC, Garcia VMT (2005) Growth and biochemical composition of the diatom Chaetoceros cf. wighamii brightwell under different temperature, salinity and carbon dioxide levels. I. Protein, carbohydrates and lipids. Aquacult 246:405-412

Ayala JF, Bravo BR (1984) Animal wastes media for Spirulina production. Arch Hydrobiol Suppl 67:349-355

Baeck SH, Shinji S, Kikuchi T (2008) Growth of dinoflagellates, Ceratium furca and Ceratium fusus in Sagami Bay, Japan: The role of temperature, irradiance and photoperiod. Harmful Algae 7:163-173

Bligh WJ, Dyer WJ (1959) A rapid method of total lipid extraction and purification. Can J Biochem Physiol 37:911-917

Borowitzka MA (1988) Vitamins and fine chemicals from microalgae. In: Borowitzka, MA, Borowitzka, LJ (eds) Micro-algal Biotechnology. Cambridge University Press, Cambridge, pp 153-196

Carvalho AP, Malcata FX (2003) Kinetic modeling of the autotrophic growth of Pavlova lutheri: study of the combined influence of light and temperature. Biotechnol Progr 19:1128-1135

Clark DR, Merret MJ, Flynn KJ (1999) Utilization of dissolved inorganic carbon (DIC) and the response of the marine flagellate Isochrysis galbana to carbon or nitrogen stress. New Phytol 144:463-470

Clark DR (2001) Growth rate relationships to physiological indices of nutrient status in marine diatoms. J Phycol 37:249-256

Davidson K, Flynn KJ, Cunningham A (1991) Relationships between photopigments, cell carbon, cell nitrogen and growth rate for a marine nanoflagellate. J Exp Mar Biol Ecol 153:87-96

Del Campo JA, Moreno J, Rodriguez H, Vargas MA, Rivas J, Guerrero M (2000) Carotenoid content of chlorophycean microalgae: factors determining lutein accumulation in Muriellopsis sp. (Chlorophyta). J Biotechnol 76:51-59

Dermoun D, Chaumont D, Thebault J, Dauta A (1992) Modelling of growth of Porphyridium cruentum in connection with two interdependent factors: light and temperature. Bior Technol 42:113-117

Dubinsky Z, Matsukawa R, Karube I (1995) Photobiological aspects of algal mass culture. J Mar Biotechnol 2:61-65

Dubois M, Gilles KA, Hamilton JK, Rebers PA, Smith F (1956) Colorimetric method for determination of sugars and related substances. Anal Chem 28:350-356

Finkel ZV, Irwin AJ, Schofield O (2004) Resource limitation alters the $3 / 4$ size scaling of metabolic rates in phytoplankton. Mar Ecol Prog Ser 273:269-279

Fuentes MMR, Fernandez GGA, Perez JAS, Guerrero JLG (2000) Biomass nutrient profiles of the microalga Porphyridium cruentum. Food Chem 70:345-353

Harding WW, Meeson BW, Fisher TR (1985) Patterns of photosynthetic carbon metabolism in light-limited phytoplankton. Mar Biol 89:121-133

Jeffrey SW, Humphrey GF (1975) New spectrophotometric equations for determining chlorophylls $\mathrm{a}, \mathrm{b}, \mathrm{c}_{1}$ and $\mathrm{c}_{2}$ in higher plants, algae and natural phytoplankton. Biochem Physiol Pflanz 167:191-194

Joo DS, Cho MG, Rainer B, Lee EH (1998) Growth and fatty acid composition with growth conditions for Spirulina platensis. J Korean Fish Soc 31:409-416

Jorgensen EG, Steeman-Nielsen E (1965) Adaptation in plankton algae. Ist Total Idrobiol 18S: 37-46

Jorgensen EG (1968) The adaptation of plankton algae II. Aspects of the temperature adaptation of Skeletonema costatum. Physiol Plant 21:423-427

Lowry O, Rosebrough NJ, Farr AL, Randall RJ (1951) Protein measurement with the Folin phenol reagent. J Biol Chem 193:265-275

Madariaga I, Joint I (1992) A comparative study of phytoplankton physiological indicators. J. Exp Mar Biol Ecol 158:149-165

Otero A, Vincenzini M (2003) Extracellular polysaccharide synthesis by Nostoc strains as affected by $\mathrm{N}$ source and irradiance. J Biotechnol 102:143-152

Ponis E, Parisi G, Le Coz J-R, Zittelli C, Tredici MR (2006) Effect of the culture system and culture technique on biochemical characteristics of Pavlova lutheri and its nutritional value for Crassostrea gigas larvae. Aquac Nut 12:322-329 
Richmond A (1986) CRC Handbook of Microalgal Mass Culture. CRC, Boca Raton, Florida

Rochet M, Legendre L, Demers S (1985) Acclimation of sea-ice microalgae to freezing temperature. Mar Ecol Prog Ser 24:187-191

Spektorova LV, Nosova LP, Goronkova OI, Albitskaya ON, Filippovskij Yu N (1986) High-density culture of marine microalgae — promising items for mariculture. 2. Determination of optimal light regime for Chlorella sp. marina under high-density culture conditions. Aquacult 55:221-229

Spolaore P, Joannis-Cassan C, Duran E, Isambert A (2006) Optimization of Nannochloropsis oculata growth using the response surface method. J Chem Technol Biotechnol 81:1049-1056

Sukenik A, Wahnon R (1991) Biochemical quality of marine unicellular algae with special emphasis on lipid composition. I. Isochrysis galbana. Aquacult 97:61-72

Sukenik A, Zmora O, Carmeli Y (1993) Biochemical quality of marine unicellular algae with special emphasis on lipid composition. I. Nannochloropsis sp. Aquacult 117:313-326

Thompson PA, Guo M (1992) Effects of variation in temperature. i. on the biochemical composition of eight species of marine phytoplankton. J Phycol 28:481-488
Thompson P (1999) The response of growth and biochemical composition to variations in daylength, temperature, and irradiance in the marine diatom Thalassiosira pseudonana (Bacillariophyceae). J Phycol 35:1215-1223

Trabelsi L, Ben Ouada H, Bacha H, Ghoul M (2009) Combined effect of temperature and irradiance on growth and extracellular polymeric substance production by the cyanobacterium Arthrospira platensis. J Appl Phycol (in press)

Valenzuela-Espinosa E, Millan-Nunez R, Trees CC, Santamaria-delAngel E, Nunez-Cebrero F (2007) Growth and accessory pigment to chlorophyll a ratios of Thalassiosira pseudonana (Bacillariophyceae) cultured under different irradiances. Hidrobiologica 17(3):249-255

Volkman JK, Jeffrey SW, Nichols PD, Rogers GL, Garland CD (1989) Fatty acid and lipid composition of 10 species of microalgae used in mariculture. J Exp Mar Biol Ecol 128:219 240

Vonshak A, Torzillo G, Boussiba S, Millie DF, Kurgens P (2000) Temperature induced photoinhibition in outdoor cultures of Monodus subterraneus. Proc. 54th Annual Meeting. Phycological Society of America, San Diego, CA 